\title{
Pengaruh Kepemilikan Institusional, Ukuran Dan Umur Perusahaan Terhadap Kinerja Intellectual Capital Industri Keuangan di BEI
}

\author{
Ainun Roviko 1 \\ I Gusti Ngurah Agung Suaryana ${ }^{2}$
}

${ }^{1}$ Fakultas Ekonomi dan Bisnis Universitas Udayana (Unud), Bali, Indonesia
email: roviko27@gmail.com / Telp : +6281239681185
${ }^{2}$ Fakultas Ekonomi dan Bisnis Universitas Udayana (Unud), Bali, Indonesia

\begin{abstract}
ABSTRAK
Menilai kinerja intellectual capital dari suatu perusahaan merupakan hal penting karena hal ini akan memberi konstribusi terhadap keunggulan kompetitif perusahaan di masa depan. Penelitian ini bertujuan untuk memperoleh bukti empiris mengenai pengaruh kepemilikan institusional, ukuran dan umur perusahaan terhadap kinerja intellectual capital industri keuangan yang terdaftar di Bursa Efek Indonesia (BEI) periode 2015 2017. Kinerja intellectual capital diukur menggunakan metode VAIC ${ }^{\mathrm{TM}}$. Penelitian ini menggunakan teknik non-probability samplingdengan metode purposive sampling dengan 37 perusahaan industri keuangan sebagai sampel dan jumlah observasi sebanyak 111 . Data sekunderdalam penelitian ini diperoleh melalui analisis laporan keuangan tahunan perusahaan sektor keuangan yang terdaftar di BEI. Hasil peneliatian ini menemukanbahwa tidak terdapat pengaruh antara kepemilikan institusional terhadapkinerja intellectual capital. Hasil penelitian ini juga menunjukkan bahwa terdapat pengaruh positif antara ukuran dan umur perusahaan terhadap kinerja intellectual capital.

Kata kunci : Kepemilikan institusional, ukuran dan umur perusahaan, industry keuangan, intellectual capital.
\end{abstract}

\begin{abstract}
ABSTRAC
Evaluate performance intellectual capital of company is an important thing because this will contribute to the company competitive advantage in the future. This study aims to obtain empirical evidence of the impact institutional ownership, firm size and firmage on intellectual capital performance financial industry listed on Indonesian Stock Exchange 2015-2017.Intellectual capital performance measured by VAIC ${ }^{T M}$. This research used non- probability sampling technique with purposive sampling method and 37 company as a sample and 111 observation. Secondary data obtained from the annual financial report of the financial industry. The result of this research indicate that institutional ownership hasnot affecting the intellectual capital performance. The result of this search also indicate that firm size and firm age has a positive effect on intellectual capital performance.
\end{abstract}

Keywords : Institutional ownership, size and firm age, financial industry, intellectual capital. 


\section{PENDAHULUAN}

Persaingan dalam era global saat ini mengalami perkembangan yang sangat pesat sehingga menghasilkan perubahan paradigma yang signifikan dari sebelumnya. Semakin ketatnya persaingan dalam dunia bisnis menuntut pimpinan perusahaan untuk mengubah pola bisnisnya dimana pola bisnis sebelumnya berupa pola tradisional yang hanya berfokus kepada sumber daya fisik menjadi pola bisnis yang berbasis pengetahuan (Tarigan,2011). Perubahan tersebut adalah perubahan pola manajemen berbasis tenaga kerja menjadi manajemen berbasis pengetahuan, sehingga karakteristik utama perusahaannya berubah menjadi perusahaan yang berbasis ilmu pengetahuan.

Pengetahuan telah diakui sebagai komponen bisnis yang penting dan sumber daya strategis yang lebih berkelanjutan untuk memperoleh dan mempertahankan keunggulan bersaing (Solikhah, 2010). Perusahaan yang menerapkan manajemen berbasis pengetahuanakan menciptakan suatu cara untuk mengelola pengetahuan yang dimiliki oleh karyawan dan perusahaan sebagai sarana untuk mencapai tujuan perusahaan. Perusahaan yang dapat menciptakan aset tidak berwujud yang baru, mengembangkan, memelihara, serta dapat memperbaharui aset tersebut maka akan memiliki kemampuan untuk mewujudkan sebuah nilai yang dalam jangka panjang dapat meningkatkan kekayaan perusahaan sehingga intellectual capital akan membuat perusahaan mampu bersaing di pasar global. (Santosus, 2002 ).

Terdapat aspek yang penting didalam keberlangsungan hidup perusahaan salah satunya adalah intellectual capital yang dipandang sebagai pengetahuan 
ISSN: 2302-8556

E-Jurnal Akuntansi Universitas Udayana

Vol.25.3.Desember (2018): 11799 - 1825

yang digunakan dalam menciptakan kekayaan perusahaan. Melalui penggunaan teknologi informasi dan ilmu pengetahuan yang tepat akan membuat perusahaan tumbuh menjadi organisasi yang berbasis pengetahuan serta memberikan keunggulan kompetitif agar perusahaan dapat memenangkan persaingan bisnis. (Yusuf dan Sawitri, 2009).

Konsep intellectual capital muncul dalam dunia bisnis yang mengakibatkan berubahnya persepsi para praktisi mengenai pengelolaan perusahaan sehingga lebih memperhatikan hal-hal mengenai nilai tersembunyi di dalam perusahaan (hidden value). Di dalam model keuangan tradisional aset tidak berwujud seperti hubungan terhadap pelanggan, kompetensi tenaga kerja, sistem komputer, administrasi dan model simulasi bisnis tidak mendapatkan pengakuan (Stewart, 1997). Bagi perusahaan berbasi teknologi maupun berbasis pengetahuan harus mampu mempertimbangkan potensi yang dimiliki oleh sumber daya manusia agar tercapai pengelolaan perusahaan yang baik.

Pada tahun 1990-an perusahaan mulai melakukan perhatian terhadap pengelolaan sumber daya yang bersumber dari berbagai jenis teknologi maupun ilmu pengetahuan sebagai aset ataupun modal perusahaan. Sering ditemukan bahwa nilai buku perusahaan lebih rendah dibandingkan dengan nilai pasarnya. Hal ini menunjukkan terdapat aset-aset di dalam perusahaan yang tidak dapat dinilai secara langsung atau tidak dapat dilihat dalam laporan keuangan tahunan. Salah satu pendekatan yang digunakan untuk menilai dan mengukur aset tidak berwujud adalah dengan intellectual capital yang menjadi perhatian dan fokus dari berbagai bidang antara lain akuntansi, manajemen, teknologi informasi, dan 
sosiologi (Guthrie dan Petty, 2000).

Salah satu faktor utama penentu perolehan laba di suatu perusahan adalah kemampuan perusahaan dalam memanfaatkan dan mengelola intellectual capital. Hal tersebut yang menjadikan intellectual capital dianggap sebagai suatu kekuatan dalam memenangkan persaingan bisnis. Menilai kinerja intellectual capital menjadi sangat penting karena dalam jangka panjang hal ini akan memberikan kontribusi terhadap peningkatan nilai perusahaan dan penciptaan keunggulan kompetitif perusahaan (Saleh et al., 2009). Nilai-nilai yang tercermin di dalam laporan keuangan yang bisa digunakan untuk mengukur seberapa besar kinerja yang dihasilkan oleh intellectual capital salah satunya adalah dengan menggunakan metode VAIC ${ }^{\mathrm{TM}}$ yang dikembangkan oleh Pulic pada tahun 1998.

Proporsi kepemilikan saham institusional yang tinggi dapat menjadi alat monitoring yang baik untuk mengawasi kinerja perusahaan sehingga hal tersebut akan meningkatkan kinerja intellectual capital. Dengan meningkatnya kepemilikan institusional akan berdampak pada berkurangnya masalah keagenan antara pemegang saham institusi. Pihak institusi akan memiliki kemampuan untuk mengawasi kinerja perusahaan melalui sarana yang memadai sehingga nilai perusahaan akan semakin meningkat (Swandari, 2008). Semakin tinggi tingkat kepemilikan institusional di dalam perusahaan maka akan membantu pengawasan terhadap pengelolaan investasi salah satunya pada intellectual capital perusahaan.Hasil penelitian oleh Putriani (2010) dan Supradnya (2016) menunjukkan bahwa kepemilikan institusional berpengaruh positif terhadap kinerja intellectual capital.Sedangkan Penelitian Dian (2011) dan Mahardika 
ISSN: 2302-8556

E-Jurnal Akuntansi Universitas Udayana Vol.25.3.Desember (2018): 11799 - 1825

(2014) menunujukkan hasil yang berbeda bahwa kepemilikan institusional tidak memiliki pengaruh terhadapkinerja intellectual capital.

Ukuran perusahaan juga menjadi aspek yang menentukan kinerja intellectual capital. Perusahaan dengan ukuran yang lebih besar memiliki akses yang lebih untuk mendapatkan pendanaan dari berbagai sumber. Sehingga dana yag diperoleh dapat dipergunakan untuk mengembangkan pengelolaah sumber daya yang dimiliki oleh perusahaan. Dengan pemanfaatan dari modal berwujud maupun modal tak berwujud yang dimiliki, perusahaan besar akan memiliki peluang yang lebih untuk mengembangkan usahanya. Investor akan lebih memperhatikan perusahaan-perusahaan berukuran besar, hal ini mengakibatkan perusahaan menjadi lebih berhati-hati dalam penerapan strateginya (Jao dan Pagalung, 2011). Hasil penelitian oleh Simanjuntak (2014) dan Ningsih ( 2016) menunjukkan terdapat hubungan positif yang signifikan ukuran perusahaan terhadap kinerja intellectual capital pada industri keuangan. Sedangkan penelitian Rahim et al. (2011) menunjukkan hasil yang berbeda bahwa ukuran perusahaan tidak memiliki pengaruh terhadap intellectual capital.

Umur perusahaan digunakan untuk mengetahui seberapa lama perusahaan dapat bertahan dalam persaingan bisnis serta secara konsisten dapat menjaga reputasi perusahaan. Semakin lama perusahaan tersebut dapat bertahan dan secara berkelanjutan dapat terus beroperasi maka akan memiliki banyak pengalaman dalam pemeliharaan dan pengelolaan intellectual capital sehingga kinerja intellectual capital akan meningkat seiring dengan lamanya perusahaan tersebut dapat terus beroperasi (Efandiana, 2011). Hasil penelitian oleh Afriani et al (2015) 
dan Mahardika ( 2014) menunjukkan adanya hubungan positif yang signifikan umur perusahaan terhadap kinerja intellectual capital. Sedangkan penelitian Putri (2011) menunjukkan hasil yang berbeda bahwa tidak terdapat pengaruh antara umur perusahaan terhadap intellectual capital.

Adanya ketidak konsistenan hasil penelitian dari hasil penelitian terdahulu yang telah dilakukan mengenai faktor-faktor yang mempengaruhi intellectual capital menjadi alasan peneliti untuk melakukan penelitian kembali.Berdasarkan uraian tersebut, peneliti tertarik untuk meneliti mengenai Pengaruh Kepemilikan Institusional, Ukuran dan Umur Perusahaan Terhadap Kinerja Intellectual Capital Industri Keuangan yang Terdaftar di BEI periode 2015-2017. Adapun rumusan masalah yang timbul berdasarkan latar belakang tersebut, yaitu apakah kepemilikan institusional berpengaruh terhadap kinerja intellectual capitalindustri keuanganyang terdaftar di BEI periode 2015-2017. Apakah ukuran perusahaan berpengaruh terhadap kinerja intellectual capital industri keuangan yang terdaftar di BEI periode 2015- 2017. Dan apakah umur perusahaan berpengaruh terhadap kinerja intellectual capital industri keuangan yang terdaftar di BEI periode 2015-2017.

Hasil penelitian ini dapat memberikan tambahan bukti empiris untuk memperkuat dukungan pada recource based theory dan stakeholder theory. Bagi perusahaan dapat memberikan informasi kepada perusahaan dalam memahami pemanfaatan intellectual capital dalam mencapai efisiensi operasional perusahaan sehingga mampu memberikan kontribusi terhadap peningkatan kinerja keuangan perusahaan. Bagi pihak manajemen dapat menjadi bahan pertimbangan dan 
masukan bagi perusahaan dalam upaya menciptakan, mengembangkan, memelihara, dan memperbaharui intellectual capital agar tercipta nilai tambah yang dapat meningkatkan profitabilitas perusahaan sehingga hal tersebut memberikan keunggulan kompetitif perusahaan serta meningkatkan daya saing.

Resource-based theory (RBT) adalah teori yang menjelaskan bahwa sumber daya perusahaan sifatnya heterogen dan jasa produktif yang tersedia berasal dari sumber daya perusahaan yang membentuk karakter unik bagi perusahaan. Dengan tepat menguasai dan memanfaakan aset-aset strategis yang penting yaitu aset berwujud dan tidak berwujud maka perusahaan akan unggul dalam persaingan bisnis (Penrose, 1959). Berdasarkan pandangan RBT, intellectual capital memenuhi kriteria sebagai sumber daya unik yang menjadi nilai tambah bagi perusahaan sehingga dapat menciptakan keunggulan kompetitif perusahaan (Wernefelt, 1984).

Resource based theory, perusahaan harus memiliki sumber daya dan kemampuan yang superior dan melebihi para kompetitornya untuk mengembangkan keunggulan kompetitif Chang dan Hsieh (2011). Melalui kemampuan dalam memanfaatkan dan mengelola kombinasi sumber daya yang tepat maka perusahaan akan memperoleh keunggulan kompetitif. Hal inilah yang membuat intellectual capital sebagai sumber daya unik bagi perusahaan untuk menciptakan nilai tambah perusahaan sehingga dalam jangka panjang akan tercapai keunggulan kompetitif perusahaan (Pramelasari, 2010).

Stakeholder merupakan kelompok maupun individu yang dapat mempengaruhi atau dipengaruhi oleh sebuah proses pencapaian tujuan suatu 
organisasi (Freeman, 1984). Pengelolaan yang lebih efektif akan terbentuk dari bantuan stakeholder kepada pihak manajemen perusahaan sehingga mereka akan lebih mengerti lingkungan perusahaan. Investor menginginkan return yang tercermin dalam laba akuntansi merupakan suatu alat ukur yang tepat dan akurat sehingga perlu adanya keakuratan dalam penciptaan return. Dalam upaya penciptaan nilai bagi perusahaan, manajemen harus mampu mengelola seluruh sumber daya yang dimiliki yaitu berupa tenaga kerja (human capital), aset fisik (physical capital) maupun structural capital (Frederick and Meek, 2010).

Keterkaitannya dengan intellectual capital, stakeholder theory dapat dipandang dari dua bidang yaitu bidang etika dan bidang manjerial. Dari sudut pandang etikastakeholder memiliki hak untuk diperlakukan secara adil oleh perusahaan dan manajer harus mengelola perusahaansebaik mungkin untuk keuntungan seluruh stakeholder. Aspek etika terpenuhi jika manajer mampu mengelola perusahaan dalam proses penciptaan nilai (Ulum, 2008).

Kepemilikan institusional menggambarkan besarnya jumlah kepemilikan saham oleh perusahaan bank, investasi, perusahaan asuransi maupun lembaga pengelolaan dana lainnya. Proporsi kepemilikan saham institusi merupakan kepemilikan saham terbesar di dalam sebuah perusahaan. Sehingga hal ini mengakibatkan peran penting dari pihak institusi dalam melakukan pengawasan perilaku manajer khususnya dalam meningkatkan take over dan memaksa manajer untuk lebih berhati-hati mengambil keputusan yang opportunistic (Listyani, 2003). 
ISSN: 2302-8556

E-Jurnal Akuntansi Universitas Udayana Vol.25.3.Desember (2018): 11799 - 1825

Ukuran perusahaan tercermin dalam nilai total aset perusahaan pada neraca akhir tahun (Sujoko dan Soebiantoro, 2007). Semakin besar ukuran suatu perusahaan maka semakin tinggi nilai total aset yang dimilikinya. Ukuran perusahaan menggambarkan besar kecilnya suatu perusahaan yang ditunjukkan oleh total aset, jumlah penjualan, rata-rata total penjualan dan rata-rata total aset yang dapat dilihat di dalam laporan keuangan tahunan.

Umur perusahaan menggambarkan seberapa lama perusahaan tersebut dapat bertahan dalam dunia bisnis yang menunjukkan kemampuan untuk memanfaatkan peluang bisnis dan mampu bersaing di pasar global (Yularto dan Chariri, 2003). Umur perusahaan dihitung dari tahun pertama perusahaan go-public sampai dengan tahun penelitian dilakukan, karena jika laporan keuangan perusahaan sudah di publikasi dan dapat diakses oleh berbagai pihak eksternal maka perusahaan akan lebih memperhatikan komponen-komponen yang tercermin di dalam laporan keuangan termasuk nilai tersembunyi dari

Terdapat tiga hal untuk memahami pengertian atas intellectual capital. Pertama, keseluruhan dari segala hal yang dapat memberikan keunggulan bersaing di dalam perusahaan dan dapat diketahui. Kedua menciptakan kekayaan serta terdapatnya ketersediaan informasi dari materi pengetahuan, fasilitasfasilitas yang dapat memadai serta pengalaman yang diperoleh. Ketiga adalah keseluruhan paket dari pengetahuan yang bermanfaat (Stewart,1997). Intellectual Capital didefinisikan sebagai segala bentuk dari pengetahuan dan informasi yang diterapkan dalam proses bekerja untuk menciptakan nilai perusahaan (Williams, 2001). Definisi lain dari Intellectual Capital adalah hasil dari ketiga elemen utama 
organisasi (structural capital, human capital, customer capital) yang berkaitan dengan teknologi dan pengetahuan serta dapat menjadi senjata berupa keunggulan bersaing bagi perusahaan yang kemudian memberikan nilai lebih bagi perusahaan (Sawarjono dan Kadir, 2003). Secara garis besar intellectual capital merupakan segala bentuk dari pengetahuan, teknologi, dan informasi yang dimiliki dan dikembangkan oleh sebuah perusahaan serta mampu diterapkan dalam kegiatan di dalam perusahaan dan dapat menambah nilai perusahaan.

Stakeholder merupakan kelompok maupun individu yang dapat mempengaruhi atau dipengaruhi oleh sebuah proses pencapaian tujuan suatu organisasi (Freeman, 1984). Pemilik saham institusi sebagai stakeholder dapat melakukan pengawasan yang lebih besar terutama jika meningkatnya kepemilikan institusional di dalam perusahaan (Supradnya, 2016). Hal ini berarti manajer harus mengelola seluruh sumber daya yang dimiliki oleh perusahaan secara optimal. Untuk meningkatkan keuntungan jangka panjang bagi perusahaan, investor institusi akan membuat kebijakan salah satunya adalah kebijakan mengenai pengelolaan intellectual capital. Kinerja intellectual capital akan meningkat seiring dengan terdapatnya investor institusional yang melakukan pengawasan optimal sehingga terjadi efisiensi dalam pengelolaan intellectual capital (Bohdannowicz, 2013). Berdasarkan uraian diatas maka hipotesis pertama dalam penelitian ini adalah sebagai berikut:

$\mathrm{H}_{1}$ : Kepemilikan institusional berpengaruh positif terhadap kinerja intellectual capital. 
ISSN: 2302-8556

E-Jurnal Akuntansi Universitas Udayana Vol.25.3.Desember (2018): 11799 - 1825

Ukuran perusahaan tercermin dalam laporan keuangan perusahaan yang berupa jumlah nilai total asset dan jumlah penjualan rata-rata (Sujianto, 2001:129). Semakin besar total aset yang tercermin di dalam laporan keuangan maka semakin besar pula ukuran suatu perusahaan. Kelompok stakeholder akan terdapat di dalam perusahaan-perusahaan besar dan melakukan pengawasan terhadap pihak manajemen dalam pengelolaan perusahaan. Stakeholder mengharapkan manajer untuk melakukan aktivitas- aktivitas dan kemudian melaporkan aktivitas tersebut kepada mereka (Purnomosidhi, 2006). Perusahaan dengan kepemilikan aset yang tinggi merupakan perusahaan besar yang juga memiliki lebih banyak dana untuk digunakan dalam pengembangan serta pengelolaan intellectual capital ( Putri, 2012). Hasil investasi dari perusahaan besar dalam pengelolaan dan pengembangan intellectual capital akan memiliki lebih banyak fasilitas- fasilitas yang memadai dibandingkan denganperusahaan kecil sehingga hal tersebut akan menarik lebih banyak investor dan tenaga kerja yang berkualitas baik.Tenaga kerja yang berkualitas baikakan memiliki kompetensi dan kecapakan yang baik dan dapat meningkatkan kinerja intellectual capital perusahaan (El-Banany, 2012). Berdasarkan uraian diatas maka hipotesis kedua dalam penelitian ini adalah sebagai berikut:

$\mathrm{H}_{2}$ : Ukuran perusahaan berpengaruh positif terhadap kinerja intellectual capital.

Resource-based theory (RBT) adalah teori yang menjelaskan bahwa sumber daya perusahaan sifatnya heterogen dan jasa produktif yang tersedia berasal dari sumber daya perusahaan yang membentuk karakter unik bagi perusahaan. Secara tepat menguasai aset-aset strategis yang penting yaitu aset berwujud dan tidak 
berwujud, maka perusahaan akan unggul dalam persaingan bisnis (Penrose, 1959). Semakin lama perusahaan berdiri maka akan menyadari pentingnya pemanfaatan dan pengelolaan intellectual capital yang tepat sehingga menciptakan keunggulan kompetitif untuk memenangkan persaingan bisnis. Umur perusahaan menggambarkan seberapa lama perusahaan tersebut dapat bertahan dalam dunia bisnis yang menunjukkan kemampuan bersaing dan memanfaatkan peluang bisnis. Semakin lama perusahaan berdiri dan beroperasi akan berdampak pada pengalaman perusahaan terhadap pengelolaan dan pemeliharaan intellectual capital sehingga pengalaman tersebutakan menjadi lebih banyak yang kemudian dalam jangka panjang dapat meningkatkan kinerja intellectual capital (Mahardika, 2014). Berdasarkan uraian diatas maka hipotesis ketiga dalam penelitian ini adalah sebagai berikut:

$\mathrm{H}_{3}$ : Umur perusahaan berpengaruh positif terhadap kinerja intellectual capital.

\section{METODE PENELITIAN}

Penelitian ini menggunakan penelitian asosiatif dengan pendekatan kuantitatif yang bertujuan untuk mengetahui hubungan antara empat variabel dengan menggunakan data kualitatif yang diangkakan (kuantitatif). Lokasi penelitian dilakukan di Bursa Efek Indonesia pada sektor keuangan. Objek penelitian ini adalah kepemilikan institusional, ukuran dan umur perusahaan serta kinerja intellectual capital padaindustri keuangan yang terdaftar di BEI periode 20152017. Data yang digunakan adalah data sekunder yang berasal dari laporan keuangan tahunan yang diperoleh dengan mengakses situs www.idx.co.id. Data diolah menggunakan aplikasi SPSS untuk mengetahui hasil dari hipotesis yang 
telah dibuat. Variabel-variabel yang digunakan dalam penelitian ini akan diuraikan dalam bentuk angka yang selanjutnya diujikan dengan uji asumsi klasik dan uji kelayakan model.

Definisi operasional variabel kepemilikan institusional adalah tingkat kepemilikan saham oleh pihak institusi seperti lembaga keuangan non bank diantaranya : perusahaan asuransi, perusahaan investasi, perusahaan reksadana dan lembaga non bank lainnya di dalam perusahaan yang diukur dalam presentase (\%). Formula untuk menghitung proporsi kepemilikan institusional adalah sebagai berikut :

Kepemilikan Institusional $=\underline{\text { Jumlah Saham Institusi }} \times 100 \%$

$$
\text { Total Saham Beredar }
$$

Ukuran perusahaan menggambarkan besar kecilnya perusahaan yang dapat dilihat dari besarnya total aset yang dimiliki pada laporan keuangan tahunan. Ukuran perusahaan dihitung mengunakan nilai natural log (ln) dari total asset perusahaan pada akhir tahun. Logaritma natural digunakan agar tidak terdapat angka desimal yang terlalu besar terhadap nilai koefisien regresi dari ukuran perusahaan karena variabel ini memiliki satuan dalam jutaan rupiah sedangkan variabel terikatnya relatif kecil sehingga penggunaan Ln akan lebih memiliki arti untuk diinterpretasikan (Safaruddin, 2011). Berikut adalah formulasi untuk menghitung ukuran perusahaan :

Ukuran Perusahaan $=$ Ln Total Aset

Dalam penelitian ini umur perusahaan dihitung dari semenjak perusahaaan pertama kali go-public sampai dengan tahun penelitian. Hal ini dikarenakan, pada saat suatu perusahaan sudah terdaftar di BEI dan go public, maka laporan 
keuangan yang diterbitkan dapat diakses oleh berbagai pihak sehingga unsurunsur dari intellectual capital dapat diukur.

Pengukuran umur perusahaan menggunakan rumus dalam penelitian yang dilakukan oleh Satoto (2009). Berikut adalah formulasi untuk menghitung umur perusahaan :

Firm age $=$ Tahun laporan keuangan terakhir (penelitian $)-$ Tahun perusahaan pertama kali go public

Variabel terikat dalam penelitian ini adalah kinerja Intellectual Capitalyang diukur menggunakan metode Value Added Intellectual Coefficient (VAIC ${ }^{\mathrm{TM}}$ ) yang dikembangkan oleh Pulic $(1998 ; 2000)$ dalam lima tahapan perhitungan yaitu sebagai berikut:

Hal pertama yang dilakukan adalah dengan menghitung Value Added (VA). VA dihitung dengan menggunakan formula sebagai berikut :

$$
\mathrm{VA}_{\mathrm{i}}=\mathrm{OUT}_{\mathrm{i}}-\mathrm{IN}_{\mathrm{i}}
$$

Keterangan :

$\mathrm{VA}_{\mathrm{i}}=$ Value Added perusahaan tahun $\mathrm{i}$ OUTi $=$ Total pendapatan dan pendapatan lain

$\mathrm{IN}_{\mathrm{i}}=$ Beban (beban operasional dan biaya lainnya selain beban karyawan).

Hal kedua yang dilakukan yaitu dengan menghitungVACA(Value Added Capital Coefficient). Jika 1 unit dari CE (Capital Employed) menghasilkan return yang lebih besar dibandingkan dengan return dari perusahaan yang lain, maka perusahaan tersebut lebih baik dalam memanfaatkan CE-nya (Pulic, 1998). Formulasi VACA yaitu :

$$
\mathrm{VACA}_{\mathrm{i}}=\underline{\mathrm{VA}_{\mathrm{i}}} .
$$


ISSN: 2302-8556

Keterangan:

$\mathrm{VAi}=$ Value Added perusahaan tahun $-\mathrm{i}$

$\mathrm{CE}_{\mathrm{i}}=$ Capital Employed perusahaan tahun- $\mathrm{i}$

Hal ketiga yang dilakukan yaitu dengan menghitung VAHU(Value Added Human Capital). VAHU menunjukkan seberapa banyak VA (Value Added) yang dapat dihasilkan dari jumlah dana yang dikeluarkan untuk berbagai keperluan tenaga kerja perusahaan.HC diambil dari beban yang dikeluarkan dalam meningkatkan kemampuan karyawan (beban dan gaji karyawan). Formulasi VAHU yaitu :

$\mathrm{VAHUi}=\underline{\mathrm{VAi}}$ (6) $\mathrm{HCi}$

Keterangan :

$\mathrm{VA}_{\mathrm{i}}=$ Value Added perusahaan tahun $-\mathrm{i}$

$\mathrm{HC}_{\mathrm{i}}=$ Human Capital perusahaan tahun i atau beban dan gaji karyawan.

Hal keempat yang dilakukan adalah dengan menghitung STVA (Structural Capital Value Added). Rasio ini mengukur jumlah structural capital yang dibutuhkan untuk menghasilkan satuan rupiah dari value add (Ulum, 2009). SC diambil dari selisih VA dengan beban yang dikeluarkan dalam meningkatkan kemampuan kayawan (HC). Formulasi STVA :

STVAi $=\underline{\mathrm{SCi}}$ (7) VAi

Keterangan :

$\mathrm{SCi}=$ Structural capital perusahaan tahun $\mathrm{i}$

$=\mathrm{VA}-\mathrm{HC}$

$\mathrm{VAi}=$ Value Addedperusahaan tahun $\mathrm{i}$

Hal kelima yang dilakukan adalah dengan menjumlahkan keempat komponen diatas yang menghasilkan besarnya Value Added Intellectual Coefficient $\left(\mathrm{VAIC}^{\mathrm{TM}}\right)$. VAIC ${ }^{\mathrm{TM}}$ mempresentasikan kemampuan intelektual perusahaan yang dapat juga dianggap sebagai BPI (Business Performance 
Indicator). Dari hasil ketiga proksi, maka dengan menjumlahkan nilai ketiganya dapat diperoleh nilai Value Added Intellectual Coefficient $\left(\mathrm{VAIC}^{\mathrm{TM}}\right)$.

$$
\mathrm{VAIC}^{\mathrm{TM}}=\mathrm{VACA}_{\mathrm{i}}+\mathrm{VAHU}_{\mathrm{i}}+\mathrm{STVAi}
$$

Penelitian ini menggunakan teknik analisis regresi untuk mengukur hubungan antara ketiga variabel di dalam penelitain dan untuk menunjukkan arah hubungan antara variabel terikat dengan variabel bebas. Analisis regresi yang digunakan dalam penelitian ini adalah analisis regresi linier berganda yang diuji dengan tingkat signifikansi 0,05 (Sugiyono, 2016:275). Model regresi linier berganda ini dirumuskan sebagai berikut :

$$
Y=\alpha+\beta_{1} X_{1}+\beta_{2} X_{2}+\beta_{3} X_{3}+e
$$

Keterangan :

$\begin{array}{ll}\mathrm{Y} & \text { : Kinerja intellectual capital } \\ \alpha & : \text { Konstanta } \\ \beta & \text { : Koefisien regresi } \\ \mathrm{X}_{1} & \text { : Kepemilkan institusional } \\ \mathrm{X}_{2} & \text { : Ukuran perusahaan } \\ \mathrm{X}_{3} & \text { : Umur perusahaan e } \quad \text { error }\end{array}$

\section{HASIL DAN PEMBAHASAN}

Penelitian ini menentukan populasi dengan targeted population. Populasinya adalah seluruh perusahaan industri keuangan yang terdaftar di BEI yaitu sebanyak 87 perusahaan. Pengambilan sampel dilakukan dengan teknik non-probality sampling dengan metode purposive sampling dan diperoleh sampel sebanyak 53 perusahaan yang memenuhi kriteria. Terjadi outlier data sebanyak 16 perusahaan. Jadi jumlah sampel yang digunakan adalah sebanyak 37 perusahaan dengan jumlah observasi sebanyak 111 yang diperoleh dari 37 x 3 ( jumlah sampel 
dikalikan jumlah periode penelitian).

Tabel 1.

Jumlah Perusahaan Sampel

\begin{tabular}{|c|c|c|c|c|c|c|}
\hline & \multirow{2}{*}{\multicolumn{2}{|c|}{$\mathbf{N}$}} & \multirow[b]{2}{*}{ in. } & $\mathbf{M}$ & \multirow[t]{2}{*}{ Me } & \multirow{2}{*}{ Deviasion $^{\text {Std }}$} \\
\hline & & & & ax. & & \\
\hline IN & & 1 & 1 & 9 & 72 & 8,1 \\
\hline S & 11 & & 6,28 & 6,99 & 18241 & 2628 \\
\hline SI & & 1 & 2 & 3 & 29 & 2,9 \\
\hline $\mathrm{ZE}$ & 11 & & 1,28 & 4,66 & 4260 & 7910 \\
\hline A & & 1 & 0 & 3 & 24 & 9,2 \\
\hline GE & 11 & & ,00 & 5,00 & 3514 & 1723 \\
\hline $\mathrm{V}$ & & 1 & 0 & 4 & 2,5 & 0,7 \\
\hline $\mathrm{AIC}^{\mathrm{TM}}$ & 11 & & ,93 & ,29 & 524 & 4123 \\
\hline
\end{tabular}

Sumber : Data diolah, 2018.

Statistik deskriptif adalah gambaran dari keseluruhan data yang dapat dilihat dari jumlah sampel, nilai minimum, nilai maksimum, nilai rata-rata (mean), dan standar deviasi dari masing-masing variabel di dalam penelitian.

Tabel 2.

\section{Hasil Statistik Deskriptif}

\begin{tabular}{lr}
\hline \multicolumn{1}{c}{ Keterangan } & $\begin{array}{c}\text { J } \\
\text { umlah }\end{array}$ \\
\hline Perusahaan industri keuangan yang listing di BEI periode 2015-2017 & 8 \\
Perusahaan yang tidak mempublikasikan laporan keuangan tahunan & 7 \\
secara berturut-turut selama periode penelitian & ( \\
Perusahaan yang mengalami kerugian selama periode penelitian & ( \\
& $5)$ \\
Outlier data & ( \\
& $16)$ \\
\hline Jumlah sampel akhir & $\mathbf{3}$ \\
& $\mathbf{7}$ \\
\hline Jumlah tahun pengamatan & $\mathbf{3}$ \\
\hline Jumlah perusahaan (x tahun) & $\mathbf{1}$ \\
& $\mathbf{1 1}$ \\
\hline
\end{tabular}

Sumber: Data diolah, 2018.

Berdasarkan tabel 2 dapat dilihat bahwavariabel kepemilikan institusional (X1) memilikinilai tertinggi sebesar 96,99 yaitu tingat kepemilikan institusional dari Bank Negara Indonesia (Persero) Tbk pada tahun 2017 nilai terendah sebesar 16,82 yaitu tingkat kepemilikan institusional dari Bank China Construction Ind. 
Tbk pada tahun 2015. Nilai rata-rata kepemilikan institusional sebesar 72,18 dan memiliki tingkat sebaran data sebesar 18,12 . Ukuran perusahaan terbesar pada industri keuangan dimiliki oleh Bank Rakyat Indonesia (Persero) Tbk dengan nilai sebesar 34,66 dan perusahaan kecil dengan nilai sebesar 21,28 adalah Verena Multi Finance Tbk. Nilai rata-rata ukuran perusahaan sebesar 29,42 dan memiliki tingkat sebaran data sebesar 2,97. Nilai tertinggi dari variabel umur perusahaan (X3) dimiliki oleh Bank Pan Indonesia Tbk yaitu sebesar 35 tahundan nilai terendah yaitu sebesar 0 tahun adalah Victoria Insurance Tbk yang merupakan salah satu perusahaan yang baru terdaftar di BEI pada tahun 2015 (tahun awal periode penelitian). Nilai rata-rata sebesar 14,35 dan tingkat sebaran data sebesar 9,21. Nilai variabel kinerja intellectual capital (Y) memiliki nilai terendah 0,93 dan nilai tertinggi 4,29 dengan nilai rata- rata 2,55 dan standar deviasi 0,74 . Nilai standar deviasi atau tingkat sebaran data dari keempat variabel berada dibawah nilai rata-rata (mean). Hal ini menunjukkan bahwa penyebaran data menunjukkan hasil yang normal dan tidak menyebabkan bias.

Selanjutnya dilakukan uji asumsi klasik yang meliputi: uji normalitas, uji multikolinearitas, uji heteroskedastisitas dan uji autokorelasi sebelum melakukan analisis dengan menggunakan teknik regresi linier berganda. Hal ini dilakukan agar model regresi memiliki data yang berdisribusi normal, bebas dari heteroskedastisitas, bebas dari multikolinearitas dan bebas dari autokorelasi. 
ISSN: 2302-8556

Tabel 3.

Uji Asumsi Klasik

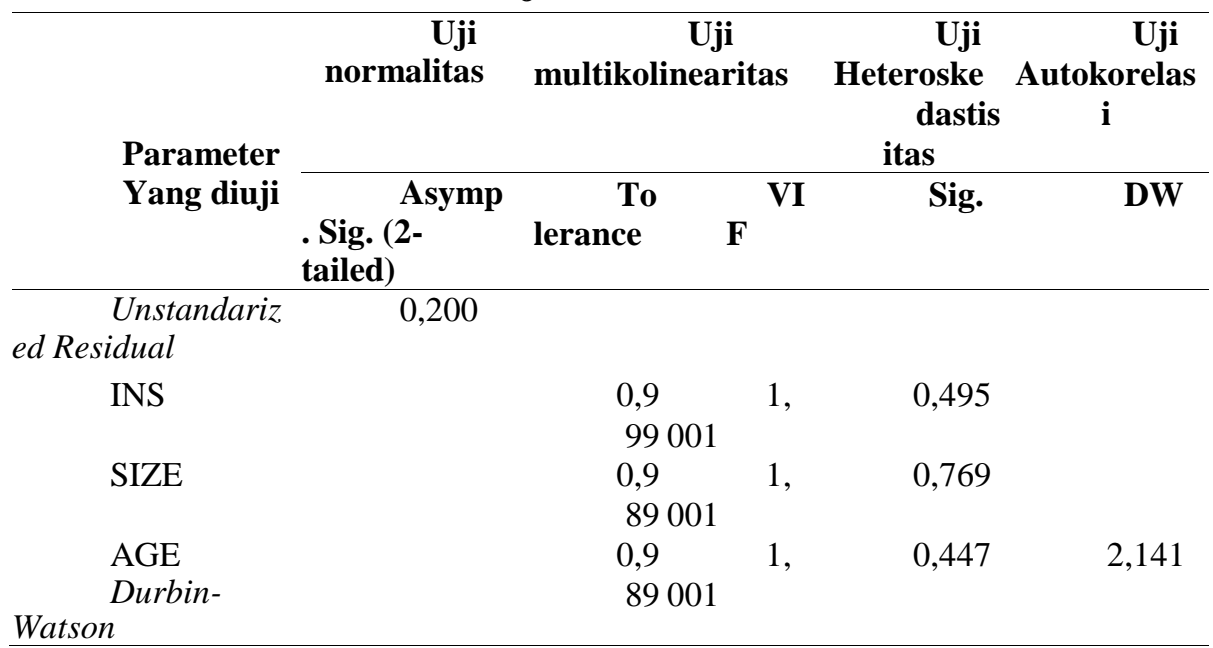

Sumber : Data diolah, 2018

Hasil Uji Normalitas menunjukkan bahwa nilai Asymp, Sig. (2-tailed) sebesar 0,200.Hal ini menunjukkan secara statistik nilai Asymp. Sig. (2- tailed) lebih besar dari 0,05 yang berarti data berdistribusi normal. Hasil uji multikolinearitas menunjukkan bahwa tidak terdapat nilai yang kurang dari 10 persen $(0,1)$ dari nilai tolerance variabel bebas dan seluruh variabel bebas memiliki nilai VIF kurang dari 10. Sehingga dapat dikatakan bahwa masingmasing variabel bebas dari multikolinearitas dan dapat digunakan dalam penelitian ini. Hasil Uji Heteroskedastisitas menunjukkan bahwa nilai signifikansi masing-masing variabel diatas 0,05 , ini mengartikan bahwa masing-masing variabel tersebut bebas dari masalah heteroskedastisitas.

Hasil uji autokorelasi menunjukkan nilai uji Durbin-Watson sebesar 2,141. Nilai $d l$ dan $d u$ dapat dilihat dari tabel durbin-watson dengan $\alpha=5 \%, \mathrm{n}=$ jumlah data, $\mathrm{K}=$ jumlah variabel bebas. Nilai $d l$ merupakan nilai durbin- watsonstatistic lower, sedangkan du merupakan nilai durbin-watson statistic upper. Maka akan 
ditemukan nilai $d l=1,61$ dan nilai $d u=1,74 ; \mathrm{K}=3$ dan $\mathrm{n}=111$. Setelah diperhitungkan dan dibandingkan dengan tabel Durbin- Watson, maka nilai sebesar 2,141 berada diantara $d u$ dan 4 - $d u$, yaitu $1,74 \leq 2,141 \leq 2,26$. Maka kesimpulannya adalah tidak terdapat autokorelasi pad model regresi dalam penelitian ini.

Analisis regresi berganda digunakan untuk mengetahui besarnya pengaruh kepemilikan institusional, ukuran dan umur perusahaan terhadap kinerja intellectual capital industri keuangan yang terdaftar di BEI periode 2015-2017.

Tabel 4.

Hasil Analisis Regresi Linier Berganda

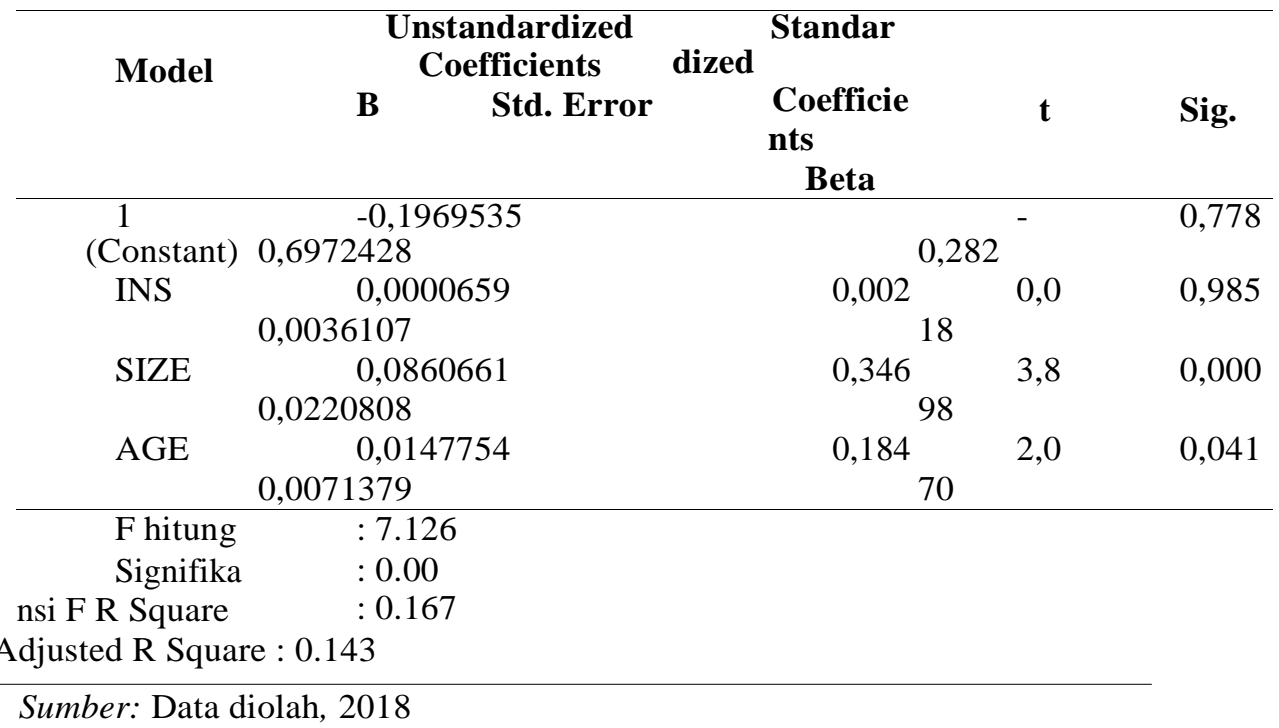

Berdasarkan hasil analisis yang disajikan pada Tabel 4 maka dapat disusun persamaan regresi sebagai berikut:

$$
Y=-0,196+0,000 X_{1}+0,0860 X_{2}+0,0147 X_{3}
$$

Nilai konstanta menunjukkan nilai negatif sebesar -0,196 yang memiliki arti jika nilai dari variabel kepemilikan institusional, ukuran, dan umur perusahaan sama dengan nol maka kinerja intellectual capital akan menurun sebesar 0,196 
satuan.Koefisien determinasi yang digunakan pada analisis regresi linear berganda adalah Adjusted $R$ Square. Nilai koefisien determinasi sebesar 0,143. Hal Ini mengartikan bahwa sebesar 14,3\% variasi kinerja intellectual capital dapat dijelaskan oleh kepemilikan institusional, ukuran perusahaan dan umur perusahaan, sedangkan $85,7 \%$ sisanya dijelaskan oleh faktor lain yang tidak diuji dalam penelitian ini.Nilai $\mathrm{F}$ hitung adalah sebesar 7,126 dengan nilai signifikansi uji $\mathrm{F}$ yaitu sebesar 0,000 lebih kecil dari 0,05 yang berarti bahwa variabel kepemilikan institusional, ukuran perusahaan dan umur perusahaan dapat atau layak digunakan untuk memprediksi variabel kinerja intellectual capital.

Nilai koefisien regresi kepemilikan institusional (X1) adalah sebesar 0,000. Hal ini menunjukkan bahwajika variabel kepemilikan institusional meningkat satu satuan maka kinerja intellectual capital perusahaan akan meningkat sebesar 0,00 yang berarti tidak terjadi pengaruh kepemilikan institusional terhadap peningkatan kinerja intellectual capital. Proporsi kepemilikan institusional pada industri keuangan di Indonesia memiliki nilai rata-rata $72,18 \%$ memungkinkan terjadinya masalah keagenan antara pemilik mayoritas sebesar lebih dari $50 \%$ dengan pemilik minoritas. Kepemilikan institusional yang terdiri dari perusahaanperusahaan pengelolaan dana di Indonesia belum mempertimbangkan intellectual capital sebagai salah satu kriteria untuk melakukan investasi, sehingga para investor tidak menuntut pihak menajemen perusahaan untuk mengungkapkan laporan mengenai intellectual capital dalam annual report yang mengakibatkan tidak terjadinya pengaruh terhadap kinerja intellectual capital di dalam perusahaan. Hasil penelitian ini sejalan dengan penelitian yang dilakukan oleh 
Dian (2011) dan Mahardika (2014) yang menunujukkan hasil bahwa kepemilikan institusional tidak memiliki pengaruh terhadap kinerja intellectual capital.

Nilai koefisien regresi ukuran perusahaan (X2) yaitu sebesar 0,0860. Hal ini menunjukkan bahwajika ukuran perusahaan meningkat satu satuan maka kinerja intellectual capital perusahaan akan meningkat sebesar 0,0860 satuan. Hasil uji statistik penelitian ini menunjukkan bahwa tingkat ukuran perusahaan memiliki pengaruh positif terhadap kinerja intellectual capital. Artinya perusahaan yang memiliki ukuran yang besar dapat memaksimalkan kinerja intellectual capital. Hal ini dikarenakan perusahaan besar akan memliki jumlah dana yang cukup besar pula untuk diinvestasikan dalam pengelolaan intellectual capital. Pemeliharaan serta pengelolaan intellectual capital menjadi semakin optimal dengan pengembangan fasilitas- fasilitas untuk menunjang kinerja intellectual capital yang lebih baik akibat dari ketersediaan dana dalam jumlah yang besar. Hasil penelitian ini sejalan dengan penelitian yang dilakukan Purnomosidhi (2006) dan Oktavianti (2014) yang menyatakan bahwa ukuran perusahaan berpengaruh positif terhadap kinerja intellectual capital.

Nilai koefisien regresi dari variabel ukuran perusahaan (X3) yaitu sebesar 0,0147. Hal ini menunjukkan bahwajika umur perusahaan meningkat satu satuan maka kinerja intellectual capital perusahaan akan meningkat sebesar 0,0147 satuan. Hasil uji statistik penelitian ini menunjukkan bahwa tingkat umur perusahaan berpengaruh positif terhadap kinerja intellectual capital. Hal ini dikarenakan umur perusahaan mencerminkan lamanya perusahaan berdiri sehingga perusahaan yang memiliki umur lebih lama dianggap telah memiliki 
pengalaman yang cukup banyak daripada perusahaan baru, selain itu perusahaan dianggap mampu menunjukkan eksistensinya dengan melakukan inovasi serta penciptaan transformasi. Hasil penelitian ini sejalan dengan penelitian yang dilakukan oleh Afriani et al (2015) dan Mahardika ( 2014) menunjukkan adanya hubungan positif yang signifikan antara umur perusahaan dengan kinerja intellectual capital.

\section{SIMPULAN}

Berdasarkan hasil analisis data dan pembahasan yang telah diuraikan diatas, maka dapat disimpulkan sebagai berikut: Tingkat kepemilikan institusional tidak berpengaruh terhadap kinerja intellectual capital $\left(\mathrm{VAIC}^{\mathrm{TM}}\right)$. Kepemilikan institusional yang tinggi akan mengakibatkan pemilik institusi lebih cenderung mendominasi perusahaan dan control dari pihak eksternal akan semakin kuat, sehingga kepemilikan institusional yang semakin tinggi akan mengurangi fokus perusahaan untuk menciptakan nilai dan kemudian dalam jangka panjang dapat mengurangi tingkat kinerja intellectual capital perusahaan. Ukuran perusahaan berpengaruh positif terhadap kinerja intellectual capital $\left(\mathrm{VAIC}^{\mathrm{TM}}\right)$. Hal ini dikarenakan perusahaan yang berukuran besar akan memiliki jumlah dana yang besar pula untuk diinvestasikan dalam mengembangkan pengelolaan intellectual capital. Hal tersebut akan berdampak pada pemeliharaan dan pengelolaan intellectual capital yang lebih baik dengan menginvestasikana dana tersebut kedalam pengembangan dan pemeliharaan fasilitas-fasilitas yang memadai guna menunjang kinerja intellectual capital.Umur perusahaan berpengaruh positif terhadap kinerja intellectual capital (VAIC $\left.{ }^{\mathrm{TM}}\right)$. Semakin lama perusahaan 
tersebut berdiri dan beroperasi, maka semakin banyak pengalaman dalam pengelolaan intellectual capital. Perusahaan akan memahami kebutuhan akan pentingnnya pengelolaan dan pengembangan sumber daya seiring dengan bertambahnya pengalaman yang dimiliki. Semakin lama perusahaan dapat bertahan dalam dunia bisnis berarti semakin banyak pengalaman yang didapat dalam pengelolaan serta tingkat pemahamannya terkait intellectual capital di dalam perusahaan, hal ini yang membuat kinerja intellectual capital dapat dioptimalkan.

Berdasarkan hasil penelitian dan simpulan diatas, maka saran yang dapat diberikan bagi pihak manajemen perusahaan diharapkan untuk memperhatikan nilai tambah (value add) yang dapat dihasilkan oleh pengelolaan intellectual capital yang optimal yaitu dengan meningkatkan ketrampilan, pengetahuan dan kompetensi karyawan melalui pelatihan serta penambahan fasilitas yang menunjang peningkatan mutu produk atau jasa sehingga berdampak pada peningkatan produktivitas karyawan serta inovasi. Serta untuk peneliti selanjutnya melakukan penelitian kembali dengan mengganti tahun pengamatan untuk mendapatkan bukti empiris dan membuktikan hasil penelitian yang konsisten. Atau dengan menggunakan variabel lainnya seperti profitabilitas dan employee profuctivity (EP) untuk mengetahui pengaruhnya terhadap kinerja intellectual capital. 


\section{REFERENSI}

Afriani, Ulfah., Nurcholisah, Kania., Nurhayati. (2015). Pengaruh Ukuran Perusahaan dan Umur Perusahaan Terhadap Kinerja Intellectual Capital (pada perusahaan perbankan yang terdaftar di BEI periode 2010- 2013).Ejournal Akuntansi Universitas Islam Bandung, 3(2),1-9.

Astuti dan Sabeni. (2005). Hubungan Intellectual Capital dan Business Performance dengan Diamond Spesification.Simposium Nasional Akuntansi VIII. Solo, 15 - 16 September.

Bohdanowicz, Leszek dan Urbanek, Grzegorz. (2013). The Impact of Ownership Structure on Intellectual Capital Efficiency: Evidence From Polish. Ejournal of economics, 8(2), 6- 49.

Bottazzi, G., A. Secchi dan F. Tamagni. (2008). Productivity, Profitability and Financial Performance.Industrial and Corporate Change. E-journal of economics,4(2), 1- 41.

Brigham, Eugene F dan J. F Houston. (2001). Manajemen Keuangan.

Terjemahan. Edisi Kedelapan. Erlangga, Jakarta.

Chang, W. S dan J. J. Hsieh. (2011). Intellectual Capital and Value Creation Is Inovation Capital. International Journal of Busniess and Management, 6 (2), 3-12.

Choi, Frederick D.S and Gary K. Meek. (2010). International Accounting. Buku 2. Salemba Empat. Jakarta.

El- Bannany, Magdi. (2008). A Study of Determinants of Intellectual Capital Performance in Banks: The UK Case.Journal of Intellectual Capital, 9(3), 487-498.

Edvinsson, L. and M. Malone. (1997). Intellectual Capital: Realizing Your Company's True Value by Finding It's Hidden Brainpower. Happer Collins, New York, NY.

Efandiana, L. (2011). Analisis Faktor-Faktor Yang Berpengaruh Terhadap Kinrja Intellectual Capital Pada Perusahaan Manufaktur yang Terdaftar di Bursa Efek Indonesia (BEI). E-journal Ekonomi Universitas Diponegoro. Semarang.

Fahmi, Irham. (2010). Manajemen Resiko. Bandung: Alfabeta.

Freeman, R. E. (1984). Strategic Management : A Stakeholder Approach, Boston, Pitman. 
Guthrie, J and R. Petty. (2000). Intellectual Capital: Australian Annual Reporting Practices. Journal of Intellectual Capital, 1(3), 241-251.

Jensen dan Meckling. (1976). Theory of the Firm: Managerial Behavior, Agency Costs and Ownership Structure.Journal of Financial Economics, 3(4), 305360.

Jao, Robert dan Gagaring Pagalung. (2011). Pengaruh Corporate Governance, Ukuran Perusahaan, dan Laverage Terhadap Manajemen Laba Perusahaan Manufaktur Indonesia.Jurnal Akuntansi dan Auditing, 8(1), 15-50.

Listyani. (2003). Kepemilikan Manajerial, Kebijakan Hutang, dan Pengaruhnya terhadap Kepemilikan Institusional, Jurnal Maksi, 3, 98112.

Mahardika, Eloking Surya., Muhammad Khalif, Linda Agustina. (2014). Pengaruh Struktur Kepemilikan, Ukuran Perusahaan, dan Umur Perusahaan Terhadap Kinerja Intellectual Capital.Accounting Analysis Journal, 3 (1), 100-108.

Penrose, E.T. (1959). The Theory of the Growth of the Firm. Oxford. Basil Blackwell.

Pulic, A. (1998). Measuring The Performance Of Intellectual Potential In Knowledge Economy. Paper Presented at the $2^{\text {nd }}$ McMaster World Congress on Measuring and Managing Intellectual Capital by the Austrian Team for Intellectual Potential. http://www.vaic-on.net. Diakses 20 Januari 2018.

Saleh, N.M., Rahman, M.R. C. A., \& Hassan, M.S. (2009).Ownership Structure and Intellectual Capital Performance in Malaysia. The Asian Academy of ManagementJournal of Accounting and Finance, 5(1), 1-29.

Santosus, M. (2002). In the Know: Trickle Up Theory, CIO Magazine, CXO Media,Inc.http://www.cio.com/research/knowledgeledit/k041902_crm. ht ml. Diakses 25 Januari 2018.

Sawarjuwono dan Kadir. (2003). Intellectual Capital: Perlakuan, Pengukuran dan Pelaporan. Jurnal Akuntansi \& Keuangan, 5(1), 35 - 57.

Stewart, Thomas. (1997). Modal Intelektual. Gramedia Pustaka. Jakarta.

Sugiyono. (2016). Metode Penelitian Bisnis. Bandung:AlfaBeta.

Sujoko dan Soebiantoro. (2007). Pengaruh Struktur Kepemilikan Saham, 
ISSN: 2302-8556

Leverage, Faktor Intern Dan Faktor Ekstern Terhadap Nilai Perusahaan.Jurnal Manajemen dan Kewirausahaan, 9,41-48.

Supradnya, I Nyoman Trisna dan I Gusti Ketut Agung Ulupui. (2016). Pengaruh Jenis Industri, Kepemilikan Manajerial, Kepemilikan Institusional, dan Kepemilikan Asing Terhadap Kinerja Modal Intelektual.E-journal Akuntansi Universitas Udayana,16 (2), 1-20.

Tarigan, Timotius. (2011). Analisis Pengaruh Intellectual Capital Terhadap Kinerja Perusahaan Sektor Farmasi yang Terdaftar di Bursa Efek Indonesia Tahun 2006-2010.E-Journal Akuntansi Universitas Diponegoro Semarang, 7 (1), 57-80.

Ulum, Ihyaul. (2009). Intellectual Capital: Konsep dan Kajian Empiris, Graha Ilmu, Yogyakarta.

Wernefelt, B. (1984). A Resource-based View of The Firm. Strategic Management Journal, Vol. 5: 171-180.

Yusuf dan P. Sawitri. (2009). Modal Intelektual dan Market Performance Perusahaan-Perusahaan yang Terdaftar di Bursa Efek Indonesia. Ejournal.Universitas Gunadarma, 2, 49-55. 